\title{
The Effect of Smartphone Addiction, Achievement Motivation, and Textbook Reading Intensity on Students' Academic Achievement
}

\author{
https://doi.org/10.3991/ijim.v13i09.9566 \\ Baidi Bukhori $(\bowtie)$ \\ Universitas Islam Negeri (UIN) Walisongo Semarang, Jawa Tengah, Indonesia \\ baidi bukhori@walisongo.ac.id \\ Hamdan Said \\ Universiti Teknologi Malaysia, Malaysia \\ Tony Wijaya \\ Universitas Negeri Yogyakarta, Indonesia \\ Faizah Mohamad Nor \\ Universiti Teknologi Malaysia, Malaysia
}

\begin{abstract}
This study investigates the effect of smartphone addiction, achievement motivation, and textbook reading intensity on academic achievement. This quantitative study involved 720 students from two public universities. The cluster random sampling technique and three psychological scales namely Smartphone Addiction Scale, Achievement Motivation Scale, and Reading Textbook Intensity Scale were employed for data collection. The data were analysed using path analysis technique. The study found that (i) smartphone addiction and achievement motivation directly affect the intensity of reading academic textbooks, and (ii) smartphones addiction, achievement motivation, and the intensity of reading academic textbooks directly affect the academic achievement. Although the intensity of reading academic textbook mediated the effect of smartphone addiction on academic achievement, it did not mediate the effect of achievement motivation on academic achievement.
\end{abstract}

Keywords - Learning achievement, reading textbook, reading intensity, smartphone addiction, achievement motivation

\section{Introduction}

Student learning achievement is the main indicator of a successful learning activity. The learning achievement that is used as the indicator must be an achievement that is obtained through optimal and quality learning process, so that it is not sort of a pseudo-achievement [1]. To obtain high achievement, students should learn optimally and make the most of their opportunities. Additionally, the students must be provided with 
conducive environment and adequate facilities and services on campus, including oneto-one assistance from academic advisors [2]-[4].

There are many factors that can affect university student achievement [5]-[8]. One of those factors is the use of media [9]. One type of media is smartphone, a portable communication device that functions like a computer and has an operating system supporting the needs of its users [10]. It has various models and standard operating systems that support internet access, email, and other features not owned by ordinary mobile phones.

Media has a strong effect, both positive and negative, on its users [11] particularly school going youths and adolescents. If used smartly, the media will have a positive effect on students' achievement. On the other hand, if used poorly, then the media will negatively affect their achievement. In the context of learning, one of the smart uses of media is to use the media reasonably to support learning, such as to access learning materials. On the other hand, one of the unwise uses of media is to overuse it and get addicted to it. One type of addiction in the use of media is smartphone addiction; generally, it is called nomophobia [12]. This smartphone addiction can simply be interpreted as the inability of individuals in controlling the use of smartphone [13].

The symptoms of smartphone addiction include:

- Inability to control craving or desire to use a smartphone. Individuals who get addicted to smartphone find it difficult not to use the smartphone

- Anxiety and feeling lost when they do not use the smartphone. Individuals feel anxious as if there is something missing in them when their smartphone is left behind, or the battery runs out

- Withdrawal and escape, that is, the smartphone is used as a means to escape when they are experiencing loneliness or problems. When the individuals are experiencing a problem or in a stressful state, then they are likely to use the smartphone for a longer time

- Productivity loss, that is, productivity decreases because the time that should be devoted for performing valuable activities is seized by the smartphone owned [14][18].

If college students get addicted to smartphone, they will not notice their time and tend to ignore their important tasks, such as reading or learning. When they have free time, they will interact more with their smartphones than with other important activities. Many of them are busy with their own smartphones to update certain status or comment on trivial issues, even when they are in the company of their friends [19].

Previous studies indicated that students who are addicted to smartphones or internet will sleep less [20]-[21]. This, thus, has an effect on their college activities and gradually results in the deterioration of their learning achievement. Other studies found that smartphone addiction negatively correlates with academic achievement [13]. The higher the addiction, the lower the learning achievement; the lower the addiction, the higher the learning achievement. This means that there is a significant effect of smartphone or internet addiction on the academic performance of students and adolescents [22]. 
In addition to smartphone addiction, learning achievement is also influenced by achievement motivation, or the need to perform and strive well for success in the form of diligent efforts in facing difficulties [23]. Individuals with high achievement motivation have certain characteristics:

- Responsible. Those high achievement motivation individuals have careful consideration and calculation because they have responsibility for solving the problems they face. This responsibility is demonstrated by choosing moderate risk challenges. Thus, they can perform tasks with ease because they have chosen risks proportional to their ability

- They are in need of feedback. Individuals with high achievement motivation want real and quick feedback on what they have done. They want to quickly improve their performance when the result of their study seems not satisfactory. Indeed, they also want to move on to other activities when the result is considered quite optimal

- They are innovative. Highly motivated individuals will continue to move to seek new information. They seem to not have too much break and avoid routines. In addition, they also have strong orientation to the future

- They are successful in their work. Good and persistent performance will be shown by individuals with high achievement motivation [24]. In this sense, achievement motivation serves as a predictor of success in the field with which they are concerned.

Motivation can determine students' success in achieving their learning goals, so that the greater the motivation, the greater the success in learning. Students of great motivation will work hard, be persistent, not give up, and diligently read books to improve their achievements. Conversely, those with low motivation seem indifferent, easy to despair, not focus on lectures, and are fond of leaving classes. As a result, they face difficulty in learning, and their achievement is usually low [25]. Studies showed that the higher the achievement motivation of the students, the higher their learning achievement [26]-[27]. Therefore, achievement motivation is very important to be owned by every student.

Additionally, student achievement is also influenced by the intensity of reading textbooks. Intensity is defined as the level of individual effort in executing an activity in both quality and quantity [28]. Reading, on the other hand, is the process of communication in the form of acquisition of information from the authors by the readers [29]. Thus, intensity of reading here is referred to the level of individual effort in obtaining information or messages given by the authors. In this study, reading is referred to reading academic textbooks.

Aspects of intensity include the frequency and the duration of time in conducting an activity [30]. Frequency is the rate of doing an activity, while duration is the time used to perform the activity. In other words, a person who has high reading intensity can be seen from the amount of time he or she allocates to reading and from the frequency of reading as well as visiting the library [30]. Reading intensity can be used as an indicator to know a person's level of motivation. A person who takes time to read a book every day indicated that he or she has high motivation to learn and broaden in- 
sight and knowledge, while those with unstable reading intensity tend to have low learning motivation.

Studies showed that the more frequent individuals perform reading activities, the better they are able to understand [31]. The more time individuals spend reading, the easier they will understand the passage [28]. Thus, the more frequent the individuals read, the higher they will achieve, mainly on cognitive aspect. Studies also showed that reading intensity had an effect on students' learning outcomes [32]-[33]. The higher the reading intensity, the higher the students' learning achievement; the lower the reading intensity, the lower their achievement.

Previous studies subjected independent variables separately, or at least they did not treat those variables simultaneously (examples [12], [21], [26], [32], [35]. Those studies employed single linear design, in which all factors are assumed to have a direct relationship to learning achievement and ignore the possibility of indirect relationships through other variables serving as mediators. This study, on the other hand, focuses on learning achievement in relation to smartphone addiction and achievement motivation, either directly or indirectly, through the intensity of reading academic textbooks.

Based on the above description, the hypotheses proposed in this study are:

- Smartphone addiction and achievement motivation affect the learners' intensity of reading academic textbooks

- Smartphone addiction and achievement motivation through the intensity of reading academic textbooks, directly or indirectly affect, the learners' learning achievement.

\section{$2 \quad$ Methodology}

The dependent variables in this research are the learning achievement and the intensity of reading academic textbook, which are affected by the two independent variables, that are, smartphone addiction and achievement motivation. Academic achievement is the result of an assessment conducted by educators on the students' learning process and outcomes as a measure of the extent to which the students have mastered the lesson they have studied. In this research, the achievement can be seen from the student's cumulative achievement index or cumulative grade point average (GPA). Intensity of reading academic textbooks is the effort done by college students when they read academic textbooks. Aspects of the intensity include:

- The frequency or the rate of reading the academic textbooks

- The duration or the time used to read those academic textbooks

In this study, smartphone addiction is defined as an individual's inability to control smartphone usage. Aspects of smartphone addiction include:

- Inability to control the desire to use a smartphone

- Anxiety and feeling lost when the student is not using smartphone 
- Withdrawal and escape from problems

- Loss of productivity. Meanwhile, in this study achievement motivation is defined as the effort to achieve success with the measure of excellent performance from either oneself or others and is proven with diligence and hard work in the face of difficulties.

Aspects of achievement motivation include:

- Responsibility

- Need of feedback

- Innovation

- Success in the given tasks

Using cluster random sampling technique, a total of 720 students from semester two to semester six who owned and used smartphone were involved in this study. Three scales were used for data collection: Textbook Reading Intensity Scale with the reliability coefficient of 0.778 , Smartphone Addiction Scale with the reliability coefficient of 0.857 , and Achievement Motivation Scale with the reliability coefficient 0.876 .

Table 1. Scales and its reliability coefficient

\begin{tabular}{|c|l|c|}
\hline No & \multicolumn{1}{|c|}{ Scale } & Reliability Coefficient \\
\hline 1 & Reading Textbook Intensity Scale & 0.778 \\
\hline 2 & Smartphone Addiction Scale & 0.857 \\
\hline 3 & Achievement Motivation Scale & 0.876 \\
\hline
\end{tabular}

\section{Results}

Prior to data analysis, multicollinearity test, heteroscedasticity test, and normality test were conducted on the data collected as suggested by [36]. The multicollinearity test of Model I and Model II was used to test whether the regression model found any correlation between the dependent variables. Based on the analysis of Model I, the VIF value was 1.006 and 1.006 , which is less than 10 . This means that there was no multicollinearity. The eigenvalue of 2.968 was far above 0 indicating the absence of the independent variable. Similarly, the analysis of Model II also found that the VIF value was $1.067,1.047$, and 1.110 , which is less than 10 . This means that there was no multicollinearity. The eigenvalue of 3.931 was far above 0 indicating the absence of the independent variable. Table 2 shows the result of multicollinearity test. 
Table 2. Results of Multicollinearity Test

\begin{tabular}{|l|l|c|c|}
\hline \multirow{4}{*}{ Model I } & \multicolumn{1}{|c|}{ Independent Variable } & \multicolumn{1}{c|}{ Collinearity Statistics } \\
\cline { 2 - 4 } & & \multicolumn{1}{c|}{ Tolerance } \\
\cline { 2 - 4 } & Achievement Motivation & 0.994 & 1.006 \\
\cline { 2 - 4 } & Smartphone Addiction & 0.994 & 1.006 \\
\cline { 2 - 4 } & - Dependent Variable: Textbook Reading Intensity & 1.067 \\
\hline \multirow{5}{*}{ Model II } & Achievement Motivation & 0.937 & 1.047 \\
\cline { 2 - 4 } & Smartphone Addiction & 0.955 & 1.110 \\
\cline { 2 - 4 } & Textbook Reading Intensity & 0.901 & \\
\cline { 2 - 3 } & - Dependent Variable: Achievement Motivation \\
\hline
\end{tabular}

Based on table 2, the tolerance value for all independent variables for Model I and Model II is bigger than 0.10. Additionally, the VIF value for all independent variables for Model I and Model II is less than 10. Based on this value, it can be concluded that there was no multicollinearity.

The heteroscedasticity test served to see whether there was a particular pattern, in which the $\mathrm{X}$ axis and the $\mathrm{Y}$ axis were predicted, and the $\mathrm{X}$ axis was the studentized residual (predicted Y - actual Y). A good model should show the absence of heteroscedasticity [37]. The result of heteroscedasticity test of Model I and Model II with graph analysis showed that there was a spread of random points either above or below 0 (zero) from the $\mathrm{Y}$ axis. This meant that there was no heteroscedasticity, so that both regression models deserved to predict the dependent variables based on the independent variables input.

The normality test was carried out to determine whether or not the regression model, the distributing variable or residual had a normal distribution. The graph was used to determine whether in a regression model, the residual regression value was normally distributed. The result of residual normality test of Model I and Model II showed that the points were spreading around the diagonal line and following its direction. This meant that both regression models met the normality assumption. After the assumption test, there was a hypothesis test. The result of data analysis using path analysis technique resulted in the following findings:

Table 3. Multiple Regression Analysis of Model I

\begin{tabular}{|l|c|c|c|}
\hline \multicolumn{1}{|c|}{ Variable } & Coefficient Regression & T count & Sig. \\
\hline Constants & 11.387 & & \\
\hline $\mathrm{X}_{1}$ (Achievement Motivation) & 0.092 & 6.608 & 0.000 \\
\hline $\mathrm{X}_{2}$ (Smartphone Addiction) & -0.080 & -5.391 & 0.000 \\
\hline F count $=39.385$ & & & \\
$\begin{array}{l}\text { Adjusted R Square }=0.096 \\
\text { Sig. } 0.000\end{array}$ & & & \\
\hline
\end{tabular}

Dependent Variable: Intensity of reading academic textbooks

Based on table 3, the probability value of t-count for independent variables, that is, achievement motivation $=0.000$ and smartphone addiction $=0,000$; both are smaller than 0.05 . This means that smartphone achievement and addiction motivation partially affect the intensity of reading academic textbooks. The probability value $\mathrm{F}$ (F-count) in multiple regression $=0.000$ is smaller than 0.05 , which means smartphone addic- 
tion and achievement motivation together influence the intensity of reading academic textbooks. The value of $\mathrm{R}$ Square is 0.096 . This shows that the contribution of smartphone addiction and achievement motivation to the intensity of reading academic textbooks is $9.6 \%$ while the remaining $90.4 \%$ is the contribution of other variables not included in the study. Meanwhile, e1 values can be found with the formula e $1=\sqrt{ }$ $(1-0.096)=0.951$. Thus, the path diagram of Model Structure I is obtained as in Figure 1 .

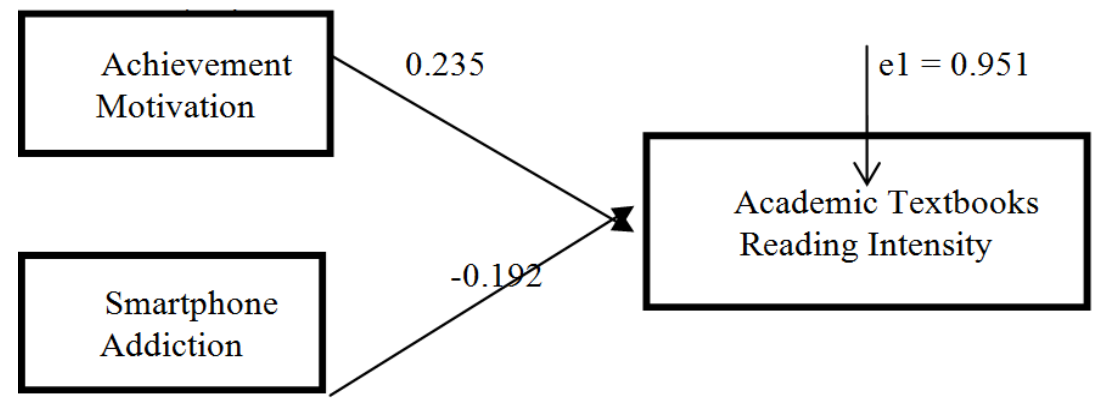

Fig. 1. Model Structure I

Table 4. Multiple Regression Analysis of Model II

\begin{tabular}{|l|c|c|c|}
\hline \multicolumn{1}{|c|}{ Variable } & $\begin{array}{c}\text { Coefficient Re- } \\
\text { gression }\end{array}$ & T count & Sig. \\
\hline Constant & 2.971 & & \\
\hline $\mathrm{X}_{1}$ (Achievement Motivation) & 0.008 & 6.183 & 0.000 \\
\hline $\mathrm{X}_{2}$ (Smartphone Addiction) & -0.003 & -2.315 & 0.021 \\
\hline $\mathrm{X}_{3}$ (Intensity of Reading Academic Textbook) & 0.012 & 3.815 & 0.000 \\
\hline $\begin{array}{l}\text { F count }=27.257 \\
\text { Adjusted R Square }=0.099 \\
\text { Sig. } 0.000\end{array}$ & & & \\
\hline
\end{tabular}

Dependent Variable: Learning achievement

Table 4 shows that the probability value of t-count for each independent variable, namely achievement motivation $=0.000$, smartphone addiction $=0.021$, and the intensity of reading academic textbooks of 0.000 ; are all smaller than 0.05 . This means that achievement motivation, smartphone addiction, and the intensity of reading academic textbooks partially affect learning achievement. The probability value $\mathrm{F}$ (Fcount) in multiple regression $=0.000$ is smaller than 0.05 , which means achievement motivation, smartphone addiction, and the intensity of reading academic textbooks together affect learning achievement. The value of $\mathrm{R}$ Square is 0.099 . This shows that the contribution of the effect of achievement motivation, smartphone addiction, and the intensity of reading academic textbooks on learning achievement is $9.9 \%$ while the remaining $90.1 \%$ is the contribution of other variables not included in the study. Meanwhile, the e2 value can be found with the formula e2 $=\sqrt{ }(1-0.099)=0.901$. Thus, the path diagram of Model Structure II is obtained as in Figure 2. 


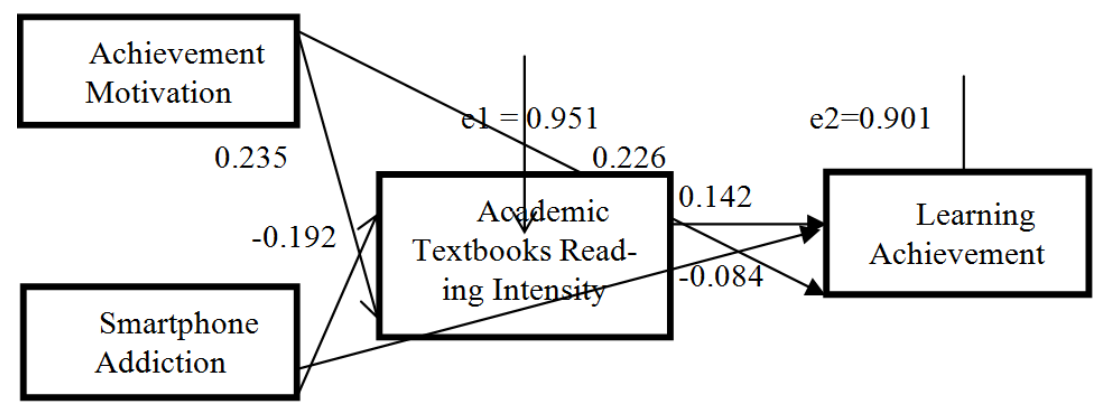

Fig. 2. Model Structure II

Based on the above analysis, it could be said that there was a directly significant effect of smartphone addiction on the intensity of reading academic textbooks since the significant value of smartphone addiction was $0.000<0.05$. There was also an effect of achievement motivation on the intensity of reading academic textbooks, since the significant value of achievement motivation was $0.000<0.05$. Therefore, it could be said that there was a directly significant effect of achievement motivation on the intensity of reading academic textbooks.

Further, based on the above analysis, it could be said that there was a directly significant effect of smartphone addiction on the learning achievement since the significant value of smartphone addiction was $0.021<0.05$. There was also an effect of achievement motivation on the learning achievement; since the significant value of achievement motivation was $0.000<0.05$. Therefore, it could be said that there was a directly significant effect of achievement motivation on the learning achievement. Finally, there was an effect of the intensity of reading academic textbooks on the learning achievement; as the significance value of the intensity of reading academic textbooks was $0.000<0.05$. Therefore, it could be said that there was a directly significant effect of the intensity of reading academic textbooks on the learning achievement.

From analysis of the effect of smartphone addiction, through the intensity of reading academic textbooks, on learning achievement, it is known that the direct effect of the smartphone addiction on the learning achievement is -0.084 . Meanwhile, the indirect effect of smartphone addiction through the intensity of reading academic textbooks on the learning achievement is the multiplication of the beta value of the smartphone addiction on the intensity of reading academic textbooks with the beta value of the intensity of reading academic textbooks on the learning achievement, i.e. $-0.192 \times 0.142=-0.027$. Therefore, the total effect given by the smartphone addiction on the learning achievement is the direct effect plus the indirect effect, i.e. $-0.084+-$ $0.027=-0.111$. Based on the above calculation, the direct-effect value is obtained as 0.084 and the indirect effect value is obtained as -0.027 , which means that the value of indirect effect is greater than that of the direct effect. It also shows that, indirectly, smartphones addiction through the intensity of reading academic textbooks has a significant effect on the learning achievement. 
From the analysis of the effect of achievement motivation, through the intensity of reading academic textbooks, on learning achievement, it is known that the direct effect of the achievement motivation on the learning achievement is 0.226 . Meanwhile, the indirect effect of achievement motivation through the intensity of reading academic textbooks on the learning achievement is the multiplication of the beta value of the achievement motivation on the intensity of reading academic textbooks with the beta value of the intensity of reading academic textbooks on the learning achievement, i.e. $0.235 \times 0.142=0.033$. Therefore, the total effect given by the achievement motivation on the learning achievement is the direct effect plus the indirect effect, i.e. $0.226+$ $0.033=0.259$. Based on the above calculation, the direct-effect value is obtained as 0.226 , and the indirect-effect value is 0.033 , which means that the value of indirect effect is smaller than that of the direct effect. It also shows that, indirectly, achievement motivation through the intensity of reading academic textbooks does not have a significant effect on the learning achievement.

Based on the above description, it can be concluded that the first hypothesis stating that smartphone addiction and achievement motivation affect the intensity of reading academic textbooks is, thus, accepted. Meanwhile, the second hypothesis stating that smartphones addiction and achievement motivation through the intensity of reading academic textbooks directly or indirectly affect learning achievement, thus, not fully accepted. Here, the hypothesis that smartphone addiction through the intensity of reading academic textbooks indirectly affects, learning achievement, is accepted. Thus, the intensity of reading academic textbooks mediates the effect of smartphone addiction on learning achievement. Furthermore, the hypothesis that achievement motivation through the intensity of reading academic textbooks indirectly affects, learning achievement is not accepted. Thus, the intensity of reading academic textbooks does not mediate the effect of achievement motivation on learning achievement.

\section{Discussion}

Based on the results of data analysis, it is known that smartphone addiction, achievement motivation, and academic textbooks reading intensity directly affect the students' achievement. The effect of smartphone addiction on learning achievement is in line with the study conducted by [22] stating that there is effect of smartphone or internet addiction on academic performance of students or adolescents. Previous studies found that smartphone addiction is negatively correlated with academic achievement [13]. The higher the smartphone addiction, the lower the learning achievement; the lower the smartphone addiction, the higher the learning achievement.

The mind and attention of students who are addicted to smartphone are always focused on the smartphone they bring to school thus; they have limited interest in other activities including learning activities whereby interest can be understood as high spirit or desire for something [38]. If students have high interest in learning activities, then they tend to be enthusiastic, attentive, and active in the learning activities. Similarly, students who have low interest in learning activities are less enthusiastic during 
the learning process. This eventually affects both their understanding of the lesson and academic achievement. The finding indicated that reading interest is positively correlated with learning achievement [39].

Smartphone addiction also affects the students' ability to manage time [12]. Students who are addicted to smartphone will spend most of their time with their smartphones, rather than with other activities. They are busy updating status on social media, giving comments to other status, or chatting through WhatsApp [13]. In addition, students who are addicted to smartphones tend to love and take advantage of various types of entertainment and facilities that can be accessed through their smartphone, such as online games, music, movies, and web-browsing to access a wide range of information. This fact results in the reduced time spent on learning. Students who have less time to study, are more likely to have lower achievement compared to those who have adequate learning time. Students who are addicted to smartphones or internet have difficulty in completing homework, preparing for exams, and allocating time for sleeping [21]. All these situations may affect the college activities and result in low learning achievement.

In addition to smartphone addiction, learning achievement is also affected by achievement motivation. The effect of achievement motivation on student achievement is in line with the study conducted by [26] dan [27] which reported that motivation has an effect on student achievement. Students with high achievement motivation often times demonstrate hard work, persistence and unwillingness to surrender, and diligence in reading books to improve their performance, whereas students with low achievement motivation seem easily discouraged, not focused on lectures, and often skipping classes. All these behaviours may result in learning difficulties and low learning achievement [25].

One of the traits of students with high-achievement motivation is that they consider and take into account the actions they will do. They also have good and effective problem-solving skills [24]. Therefore, in the learning process, they completed the college tasks well and on time. Students with high-achievement motivation believe that the college tasks are very influential on their achievement index or the GPA to be obtained. If the tasks are done well, their achievement is certainly good. Besides, the characteristic of students with high achievement motivation is that they are individually in need of feedback for what they have done. If the result of their learning is less satisfactory, then they will immediately fix it because they also have a good recovery. Feedback does not make them feel bad or worse. In fact, it makes them more motivated to get better results or achievements.

Furthermore, learning achievement is also affected by the intensity of reading academic textbooks. The effect of the intensity of reading academic textbook on learning achievement is in line with the result of [32] and [33] which showed that reading intensity has an effect on student achievement. The higher the intensity of reading, the higher the students' learning achievement; the lower the reading intensity, the lower the students' achievement. Students with high reading intensity have wider knowledge than those with low reading intensity. This can be understood from the fact that learning achievement is obtained through the learning process to gain knowledge, and gaining knowledge is done through increasing the reading intensity, especially aca- 
demic textbooks. In line with that, [40] views reading activity as the heart of education. More specifically, reading is likened to the lifeblood of education. This means that there is no educational activity without reading.

Given the importance of reading activities, reading is a crucial activity that should be a distinct trait of college students. If reading academic textbooks has become the habit of college students, then their achievement will be better because high achievement is one indicator that they have extensive knowledge [41]. In line with that opinion, [31] stated that the more frequent the individual performs reading activities, the better they are able to understand lessons. This leads of course to the increase in their learning achievement, especially in cognitive aspects.

The findings of this study showed that the hypothesis stating that smartphones addiction through the intensity of reading academic textbooks, indirectly affects, learning achievement', is accepted. This means that the variable 'intensity of reading academic textbooks' helps to negate the effects of smartphone addiction on learning achievement. This is because smartphone addiction plays a serious role in reducing the student's behavioural control in reading; it directly controls the intensity of reading. In addition, they tend to lose time, especially time for reading. This opinion is in accordance with the concept proposed by [42] that behaviour can be predicted if the individual is able to control all possible factors, or when they do nothing. These 'possible' factors can be internal factors like competency including the ability to understand reading materials and the availability of time for conducting such an activity, or external factors like the availability of tools including books and other resources that are needed in doing such an activity, such as a convenient place to read. When individuals are addicted to smartphones, they do not have the ability to control their behaviour, so their reading intensity decreases, and this eventually results in the drop in achievement.

The finding of this study also showed that the hypothesis stating that achievement motivation through the intensity of reading academic textbooks indirectly affects learning achievement is not accepted. It means that the variable 'intensity of reading academic textbooks' cannot be used as an intermediate effect of achievement motivation on learning achievement. Achievement motivation has a direct role to play on learning achievement, while the intensity of reading academic textbooks does not have a total effect on achievement motivation. In fact, achievement motivation also depends on other factors, such as learning style [43]. Intensity is temporary and nonpermanent because it is also affected by comfort and other social factors [44]; it is, hence, changeable, unlike the motivational factors that are more permanent. This is also supported by the intentional concept developed by [42] that states that the intentional relationship with behaviour is not entirely dependent on motivational factors but are dependent on behavioural controls, in this case such as the time to read and the access to reading. 


\section{Conclusion}

This study concludes that smartphone addiction and achievement motivation affect the intensity of reading academic textbooks. The higher the smartphone addiction, the lower the intensity of reading academic textbooks; the lower the smartphone addiction, the higher the intensity of reading academic textbooks. Similarly, the higher the achievement motivation, the higher the intensity of reading academic textbooks; the lower the achievement motivation, the lower the intensity of reading academic textbooks.

In addition, smartphone addiction indirectly affects, through the intensity of reading academic textbooks, the learning achievement. The intensity of reading academic textbooks, thus, mediates the effect of achievement motivation on learning achievement. On the other hand, achievement motivation does not have an indirect effect, through the intensity of reading academic textbooks, on learning achievement. Thus, the intensity of reading academic textbooks does not mediate the effect of achievement motivation on learning achievement.

For future researchers, it is important to conduct research involving external factors that affect the learning achievement. By involving these factors or variables, it is expected that the understanding of the factors affecting the learning achievement will be more comprehensive. For educators, it is urgent that they remind the students not to get addicted to smartphones; the students should use smartphones smartly and wisely, that is, to support the success of learning, such as to access learning materials. In addition, trainings should be held to increase one's achievement motivation and book reading intensity. For college students, they should avoid smartphone addiction and use them only for the purpose of supporting academic achievement [45]-[47]. In addition, they should also increase their achievement motivation and book-reading intensity.

\section{References}

[1] Andriani, V. (2005). Hubungan minat profesi pendeta dan konsep diri dengan prestasi akademik mahasiswa Sekolah Tinggi Theologia HKBP Pematang Siantar. (Unpublished Thesis). Yogyakarta: Sekolah Pascasarjana Universitas Gadjah Mada. https://doi.org/10. 32832/tek.pend.v6i1.505

[2] Van, N. T., Said, H., Awang, Z., \& Khan, A. (2016). Student perspective on learning and development outcomes of academic advising at Universiti Teknologi Malaysia. Man in India, 96(1-2), 675-688.

[3] Van Nguyen, T., Said, H., Khan, A., \& Ghani, F. A. (2017). Academic advising models and practices of two Asian universities. Man in India, 97(19), 33-41.

[4] Van, N. T., Said, H., \& Khan, A. (2016). Components of an academic advising program standard for Malaysian public universities. Man in India, 96(6), 1691-1702.

[5] Alshammari, F., Saguban, R., Pasay-an, E., Altheban, A., \& Al-Shammari, L. (2018). Factors affecting the academic performance of student nurses: A cross-sectional study. Journal of Nursing Education \& Practice, 8(1), 60-68. https://doi.org/10.5430/jnep.v8n1p60. 
[6] Mushtaq, I., \& Khan, S. N. (2012). Factors affecting students' academic performance. Global Journal of Management \& Business Research, 12(9), 17-22. https://doi.org/10. $\underline{5430 / \text { jnep.v8n } 1 \text { p60 }}$

[7] Rossi, M. (2017). Factors affecting academic performance of university evening students. Journal of Education and Human Development, 6(1), 96-102. https://doi.org/10.15640/ jehd.v6n1a10

[8] Thawabieh, A. M. (2016). Factors affecting university students' achievement. British Journal of Education, Society \& Behavioral Science, 14(4), 1-11. https://doi.org/10. 9734/BJESBS/2016/23334

[9] Andri, A., Zagir, Z, \& Dores, O. J. (2017). Analisis faktor-faktor yang mempengaruhi rendahnya prestasi belajar siswa pada mata pelajaran matematika di SD Negeri 04 Bati Tahun Pelajaran 2016/2017. Jurnal Pendidikan Dasar Perkhasa, 3(2), 414-426. https://doi.org/10. 31932/jpdp.v5i1.362

[10] Syafrida, R. (2014). Regulasi diri dan intensitas penggunaan Smartphone. Jurnal Pendidikan Usia Dini, 8(2), 353-363. https://doi.org/10.21107/jpgpaud.v5i2.4884

[11] Schmidt, M. E., \& Vandewater, E. A. (2008). Media and attention, cognition, and school achievement. The Future of Children, 18(1), 63-85. https://doi.org/10.1353/foc.0.0004

[12] Davie, N., \& Hilber, T. (2017). Nomophobia: Is smartphone addiction a genuine risk for mobile learning. Paper presented at the International Association for Development of the Information Society (IADIS) on the $13^{\text {th }}$ International Conference on Mobile Learning (Budapest, Hungary, Apr 10-12, 2017).

[13] Samaha, M. S., \& Hawi, N. (2016). Relationships among smartphone addiction, stress, academic performance, and satisfaction with life. Computers in Human Behavior, 57(2016), 321-325. https://doi.org/10.1016/i.chb.2015.12.045

[14] Chaudhury, P., \& Tripathy, H. K. (2018). A study on the impact of smartphone addiction on academic performance. International Journal of Engineering and Technology, 7(2.6), 50-53. https://doi.org/10.14419/ijet.v7i2.6.10066

[15] Haug, S., Castro, R. P., Kwon, M., Filler, A., Kowatsch, T., \& Schaub, M. P. (2015). Smartphone use and smartphone addiction among young people in Switzerland. Journal of Behavioural Addictions. Akademiai Kiado, 4(4), 299-307. https://doi.org/10.1556/2006.4. $\underline{2015.037}$

[16] Kim, D., Chun, H., \& Lee, H. (2014). Determining the factors that influence college students' adoption of smartphones. Journal of the Association for Information Science and Technology, 65(3), 578-588. https://doi.org/10.1002/asi.22987

[17] Aljomaa, S. S., Al-Qudah, M. F., Albursan, I. S., Bakhiet, S. F., \& Abduljabbar, A. S. (2016). Smartphone addiction among university students in the light of some variables. Computers in Human Behaviour, 61(2016), 155-164. https://doi.org/10.1016/i.chb. 2016.03.041

[18] Leung, L. (2008). Leisure boredom, sensation seeking, self-esteem, and addiction: Symptoms and patterns of cell phone use. Mediated Interpersonal Communication, 379381. https://doi.org/10.4324/9780203926864

[19] Muna, R. F. \& Astuti, T. P. (2014). Hubungan antara kontrol diri dengan kecenderungan kecanduan media sosial pada remaja akhir. Empat: Jurnal Karya Ilmiah S1, 3(4), 481-491. https://doi.org/10.30738/spirits.v4i2.1117

[20] Hawi, N. S., \& Samaha, M. (2016). To excel or not to excel: Strong evidence on the adverse effect of smartphone addiction on academic performance. Computers \& Education, 98(2016), 81-89. doi: https://doi.org/10.1016/j.compedu.2016.03.007

[21] Young, K. S. (2004). Internet addiction. American Behavioral Scientist, 48(4), 402-415. 
[22] Kakkar, N., Ahuja, J., \& Dahiya, P. (2015). Influence of internet addiction on the academic performance and mental health of college students. Scholarly Research Journal for Interdisciplinary Studies, 3(21), 1151-1161.

[23] Singh, K. (2011). Study of achievement motivation in relation to academic achievement of students. International Journal of Educational Planning \& Administration, 1(2), 161-171.

[24] McClelland, D. C., Patel, V., Stier, D., \& Brown, D. (1987). The relationship of affiliative arousal to dopamine release. Motivation and Emotion, 11(1), 51-66. https://doi.org/ 10.1007/BF00992213

[25] Mudzakir, A., \& Sutrisno, J. (1997). Psikologi pendidikan. Bandung: Pustaka Setia.

[26] Narwoto, N., \& Soeharto, S. (2014). Faktor-faktor yang berpengaruh terhadap prestasi belajar teori kejuruan siswa SMK. Jurnal Pendidikan Vokasi, 3(4), 222-233. https://doi.org/10.21831/jpv.v3i2.1603

[27] Kumari, V. R. S., \& Chamundeswari, S. (2015). Achievement motivation, study habits and academic achievement of students at the secondary level. International Journal of Emerging Research in Management \& Technology, 4(10), 7-14.

[28] Bukhori, B. (2005). Intensitas dzikir dan agresivitas pada santri. Jurnal Psikologi Islam, $1(2), 141-152$.

[29] Zuchdi, D. (2008). Strategi meningkatkan kemampuan membaca. Yogyakarta: UNY Press.

[30] Lubis, L. H., Tobing, M., \& Tampubolon, H. (2008). Pengaruh strategi pembelajaran dan minat baca terhadap hasil belajar membuat hiasan busana dari siswa SMK Negeri 10 Medan. (Unpublished Research Report). Medan: Universitas Negeri Medan. https://doi.org/10.24114/jpp.v18i3.4294

[31] Tampubolon, D. P. (1990). Kemampuan membaca: Teknik membaca efektif dan efisien. Bandung: Angkasa.

[32] Farida, U. N. (2016). Pengaruh intensitas membaca terhadap hasil belajar siswa mata pelajaran bahasa Indonesia di Madrasah Ibtidaiyah al-Dloruriyah Sidokerto Mojowarno Jombang tahun ajaran 2015-2016. (Unpublished Essay). Jombang: Universitas Pesantren Tinggi Darul 'Ulum. https://doi.org/10.30736/akademika.v11i1.41

[33] Prihandini, L. (2016). Pengaruh intensitas membaca terhadap hasil belajar IPS siswa kelas V SD se-Gugus II Kecamatan Pengasih Kabupaten Kulon Progo tahun pelajaran 2014/2015. Jurnal Pendidikan Guru Sekolah Dasar, 5(2), 121-128. https://doi.org/ 10.17509/eh.v4i1.2819

[34] Awan, R. U. N., Noureen, G., Naz, A. (2011). A study of relationship between achievement motivation, self-concept and achievement in English and Mathematics at secondary level. International Education Studies, 4(3), 72-79. https://doi.org/10.5539/ies.v4n3p72

[35] Sikhwari, T. D. (2014). A study of the relationship between motivation self-concept and academic achievement of students at a University of Limpopo Province, South Africa. International Journal Educational Science, 6(1), 19-25. https://doi.org/10.1080/097511 22.2014 .11890113

[36] Retherford, R. D., \& Choe, M. K. (1993). Statistical models for causal analysis. New York: John Wiley \& Sons. https://doi.org/10.1002/bimj.4710360809

[37] Priyatno, D. (2012). Belajar cepat olah data statistik dengan SPSS. Yogyakarta: Andi Publisher.

[38] Syah, M. (2003). Psikologi pendidikan. Bandung: Remaja Rosdakarya.

[39] Marlina, L., Caska, \& Mahdum. (2017). Hubungan minat baca dan motivasi belajar dengan hasil belajar ekonomi kelas XI IPS SMAN 10 Pekanbaru. Jurnal Pendidikan Ekonomi dan Bisnis, 9(1), 33-47. https://doi.org/10.26740/jepk.v4n2.p121-135

[40] Iswara, P. D. (1996). Kebahasaan dan membaca dalam bahasa Indonesia. Jakarta: Bagian Proyek Penataran Guru SLTP Setara D-III, Direktorat Jenderal Pendidikan Dasar dan 
Menengah, Departemen Pendidikan dan Kebudayaan. https://doi.org/10.24832/ jpnk.v18i4.102

[41] Slameto. (2007). Belajar dan faktor-faktor yang mempengaruhinya. Jakarta: Rineka Cipta

[42] Ajzen, I. (2005). Attitudes, personality and behavior ( $2^{\text {nd }}$ ed.). Berkshire, United Kingdom: Open University Press-McGraw Hill Education.

[43] Bire, A. L., Geradus, U., \& Bire, J. (2014). The effects of visual, audio, and kinestetic learning styles on the academic achievement of students. Jurnal Kependidikan, 44(2), 168174.

[44] Chiang, H. S., \& Chen, C. C. (2014). Exploring switch intention of users' reading behaviour: An e-book reader case study. The Electronic Library, 32(4), 434-457. https://doi.org/10.1108/el-06-2012-0070

[45] Alwraikat, M. (2017). Smartphones as a new paradigm in higher education overcoming obstacles. International Journal of Interactive Mobile Technologies, 11(4), 114135. https://doi.org/10.3991/ijim.v11i4.6759

[46] Alfawareh, H. M., \& Jusoh, S. (2017). The use and effects of smartphones in higher education. International Journal of Interactive Mobile Technologies, 11(6), 103111. https://doi.org/10.3991/ijim.v11i6.7453

[47] Yunita, A., Nursechafia, N., Setiawan, E., Ngroho, H., \& Ramadhan, H. (2018). The relationship between mobile phone usage in classroom and academic achievement in college life. International Journal of Interactive Mobile Technologies, 12(8), 96103. https://doi.org/10.3991/ijim.v12i8.9530

\section{$7 \quad$ Authors}

Baidi Bukhori is a lecturer and researcher at the Faculty of Psychology and Health of the Universitas Islam Negeri (UIN) Walisongo Semarang, Indonesia. He teaches undergraduate and postgraduate programmes. He is the Chief Editor for the Journal of Psikohumaniora which is published by the Faculty of Psychology and Health, Universitas Islam Negeri (UIN) Walisongo Semarang, Indonesia.

Hamdan Said is a Professor of Higher Education at School of Education, Universiti Teknologi Malaysia. He teaches a few courses for Educational Management and Administration Programme at postgraduate level and Teacher Education Programme at undergraduate level. His research interests include geography of higher education, academic leadership, college student development, and creativity and innovation in teaching and learning in higher education.

Tony Wijaya is a lecturer and researcher of Yogyakarta State University. He has expertise in behavioural and statistical sciences. He teaches statistical courses at postgraduate level and teacher of consumer behaviour at undergraduate level.

Faizah Mohamad Nor is an Associate Professor at Language Academy, Universiti Teknologi Malaysia. She teaches language, research methodology and ESL teaching methodology courses at undergraduate and postgraduate levels. Her research interests include teacher training, language learning strategies and English for Specific Purposes.

Article submitted 2018-09-19. Resubmitted 2019-04-04. Final acceptance 2019-04-21. Final version published as submitted by the authors. 